\title{
Virtual Pesantren Management in Indonesia: In Knowing Locality, Nationality, and Globality
}

\author{
Mukhibat \\ Institut Agama Islam Negeri (LAIN) Ponorogo \\ e-mail:mukbibat@iainponorogo.ac.id
}

\begin{abstract}
Virtual Pesantren is a new model of Islamic boarding school with no real form and place but having a similar function as a pesantren as a tafaqquh $f i$ al addin institution. The characteristic of this pesantren is on its material development which is adjusted to the virtual students' needs with the use of appropriate language and relevant content so that it is easily understood. The problem occurs when the virtual pesantren raises an issue of the extreme purification practice that questions the authenticity of religion. This has led to a decline in the pesantren's historical vision - Islam and Indonesian (indigenous). The analysis of this study is descriptive qualitative. The report is presented in the form of a comprehensive and objective narrative based on data that has been classified and verified beforehand. Given these findings, pesantren is fundamentally built based on vision of pesantren which is tasamuh, tawassuth, and tawazun. Pesantren must be able to create a continuity and change in bonding between the values of locality, nationality, and globality as the basis of pesantren development.
\end{abstract}

Keywords: globality, indigenous, nationality, pesantren virtual, subculturelocality

\section{A. Introduction}

Various studies on pesantren, came to the conclusion that the terminology of pesantren or Islamic School indicates that pesantren is culturally born from Indonesian culture, it is from Madjid (1997) argues, historically pesantren not only contain Islamic meaning, but also the meaning of authenticity of Indonesia (indigenous) (Yasmadi, 2002: 62). In the structure of national education, pesantren is a very important chain. This is not only because of its very long history of emergence, but because pesantren have significantly played a major role in the effort to educate the nation's life (Mukti, 2002: 1). Wahid (2001) defines pesantren as a place where santri live. While Mahmud Yunus (1990) said that pesantren is a place for students to study Islam. 
Mid the strengthening of cultural globalization which has led local culture to the brink of extinction, this is marked by the emergence of transnational ideology (Bhagaskoro, Pasopati, Syarifuddin, 2019: 114). Incessant transnational ideology that is spread in public space, and the accompanying conversations lately do not necessarily undermine the existence of local wisdom. Therefore, role of pesantren as a rooted institution in the community should improve its function as a center for the preservation and development of local culture. For this reason, pesantren must continuously innovatively ground the universal Islamic teachings following the local cultural conditions of the archipelago. Because of the local culture, besides being a national identity, there are exotic-philosophical values which are very valuable for the life process. So that it is not a few circles of Indonesian Islamic scholars call pesantren as a "subculture" of the archipelago culture. This cannot be separated from the efforts of the spreaders of Nusantara Islam, especially $W$ alisongo, who prioritize the principle of dialogue, both in daily communication activities and local cultural dialogue (Mukhibat, 2015: 178).

The predicate is a "subculture", "cultural broker", and at the same time "cultural filter" above is look interesting when taken in the context of the current information age, where the students of pesantren have begun meeting the internet. Along with the accelerating technology that is so massive today, the world community has now been transformed into an "information society" or "digital society" (digital society) (Adib, 2013: 2). The encounter with the internet could threaten the predicate of pesantren as a "subculture" because pesantren has become part of the "global village". This development allows the virtual media to be an alternative in the context of showing the dakwah (religious preaching).

The broadcasting of religious preaching was captured in designing by Muslims have development of a Virtual Islamic School (Ghofar 2017:778) which is a form of a new Islamic boarding school that does not have a real form and place, but has the same function as other "conventional" boarding schools, namely as a tafaqquh fiddin institution that provides religious guidance.

The observing of pesantren in facing the challenges have responses are certainly very interesting. It appears that pesantren are facing a problematic situation between the fulfilment of the need to absorb information from outside which is increasingly growing, on the one hand, and a commitment to maintaining the basic character of pesantren, on the other of. This situation, borrowing the phrase Peter Mandaville (2009), pesantren is in the flow of "digitalization" of Islam which has become a global symptom of the Islamic world today, where the boundaries of religious knowledge are changing in such away. The photographing pesantren responses to global developments and maintaining human rights is indeed not so easy, because the dynamics of religious thought and institutional development in the pesantren world are quite complex. However, this dynamic can actually be photographed, although it may not be satisfactory, using the perspective of "cultural gap" (cultural lag), namely the situation where the non-material world of culture is not able to follow the pace of development in the world of material culture, where the result that emerges is "cultural shock" (cultural shock) which can cause new problems for pesantren. The condition of such pesantren, the idealism that the pesantren wants to achieve that are built based on the pesantren's vision and mission will experience difficulties in achieving it.

The study of the existence of pesantren in the framework of developing local cultural values as the original character of pesantren in global development is increasingly important. National Education System No. 20 of 2003, as a new "ammunition" pesantren which positions it on a par with other education (Ali 2010: 35). This condition is very positive as well as a challenge for pesantren in reinforcing the vision of pesantren locality culture in a national and global context. It is hoped that with this study, it will dismiss the notion that local and modern culture is not an 
enemy of pesantren and even becomes a platform for pesantren in Indonesia, should it maintain its historical traditions or adopt new developments in the whole process of education? In addition, this study also wants to emphasize that pesantren are including virtual pesantren has a tradition of developing local wisdom and Indonesianness that consistently wants to create a humanistreligious life in local, national and global contexts. This study becomes very relevant to mukhibat's research (2014) which explains that the pesantren are now appearing more to show the flow of thought, ideology and social groups and the activities of the movement that often opposes Islam and local wisdom.

\section{B. Literature Review}

Virtual pesantren is one of the form of a development of virtual organizations (Mukhibat, Ghafar, 2019). The initiative to establish a virtual pesantren initially took place in an intellectual discussion forum on the internet. Those involved were Arif Hidayat and Arif Rokhmad-Widianto. Arif Hidayat is a board member of Da'wah (religious preaching), an alumnus of the Kajen Islamic Boarding School, Pati, Central Java who is studying religion in Cairo. The naming of virtual pesantren is based on two reasons. First, admiration, takhdim or devotion and pride in the progress of pesantren as the longest (traditional) formal education institution in Indonesia. Secondly, these students felt that the presence of this pesantren had no real form and place, hence it was called virtual. The virtual Islamic boarding school wants to be an Islamic study and teaching institution through the internet, besides providing religious guidance to the community, it also runs scientific and Islamic development programs.

Thus the virtual pesantren can be said as one form of development of pesantren education by utilizing technology and information (Damanhuri, Mujahidin, and Hafidhuddin 2013:17), the early history of the development of pesantren in Indonesia became a center of education for ulama (Islamic scholar) cadres, in addition to being a development center for Islamic symbols (Muhakamurrohman 2014: 109). Although the form and model of virtual pesantren are very different from traditional or modern (Aziz and Taja, 2016: 9) pesantren where the difference lies in the boarding and worship facilities supporting pesantren, the core of the Pesantren Virtual is moral education and Islamic studies (Djasadi, 2014).

The question is, can the Institutional virtual pesantren be called pesantren as long as they exist and exist in Indonesia? Traditionally pesantren, an Islamic educational institution can be called pesantren if it has the main elements that are commonly known in the pesantren world. According to experts, pesantren can only be called pesantren if they meet five conditions, namely (1) Kiai (Islamic teacher), (2) Islamic boarding school, (3) mosque, (4) santri (student), and (5) kitab kuning learning (Islamic holy book). The third requirement, the mosque, is not just a place of worship but as a mediator of the transfer of knowledge from the Kiai to his students. The mosque also functions as a center for santri activities such as mubâdlarah (lectures), bahts al-mas'il (discussing issues), and so on (Tafsir 2008:191). According to the Director of Diniyah Education and Islamic Boarding School of the Ministry of Religion, Ahmad Zayadi, said that this model boarding school is more accurately referred to as an online study. Because of according to him, some requirements must be met so that religious learning institution is referred to as pesantren.

Then how are virtual pesantren seen from Islamic boarding school nomenclature and educational institutions under the Ministry of Religion? The category is in the national education system, especially in pesantren education does not exist. Even if the equivalent is sought in the type of Islamic religious education or other types of education, regulations in the Ministry of Religion 


\section{Mukhibat}

do not cover the types of activities of the virtual pesantren. It might be more appropriate to use the term virtual/online study to describe the activities and activities in the virtual pesantren. It has reason, if you use the term pesantren, of course, you must meet the provisions that have been in effect, namely meeting the pesantren pillars, namely, Kyai/Nyai (teachers) or other names as leaders/caregivers of pesantren; Mosque /masala; Dormitory/cottage; Santri Mukim (students); Study the kitab kuning (Ilyasin, 2020: 18). In addition to meeting the pesantren pillars, there are also provisions regarding pesantren souls (rubul ma'had), which must be developed by each pesantren institution which includes: Soul of the Republic of Indonesia and nationalism, science, spirit of sincerity, spirit of simplicity, spirit of unity, spirit of independence, spirit of freedom, balance soul, tasamuh, tawassuth, and tawazun (Kholil, 2011: 306).

Also, studying in the pesantren is not only "learning about religion", but "learning about how to religion", therefore there is a Kail nyai figure, who provides guidance, irshadat, provides role models in life. Kyai also with sincerity always prayed for his students to be good individuals. Also, in the scientific tradition at the pesantren, the learning process of the books is carried out with typical pesantren learning methods such as bandongan and sorogan, all of which require "the teacher meets with students". This is related to the scientific sanad which must be derived directly from the religious teachers to students.

Observing the description of the Virtual Islamic Boarding School above, the Virtual Islamic Boarding School is still far from the vision of the pesantren historicity that has been attached to the pesantren as well as preserving culture and tradition, both Islamic and local traditions. But what is clear is the existence of the Virtual Pesantren as one of the educational strategies and Islamic preaching in the contemporary era to be one effective strategy (Saputra, Nazim, and Islamiyah 2017: 797). It is seen, where are many millennial generations' behaviors utilize technology and information in each of their activities. Indonesia occupy in the sixth position as the most internet user in the world (Supratman, 2018). Increasing the number of internet accesses is a sign of changes in Indonesian people's behavior, virtual lifestyles have changed the shape of the organizational model, virtual organizations continue to develop in various designs and forms (Wiesenfeld, Raghuram, and Garud 1999) where one of them is a virtual boarding school. The approach to education studies in virtual pesantren is a combination of traditional and modern methods by following various dynamic modern problems.

\section{B. Research Methodology}

The connection between globalization and pesantren readiness and repositioning in facing it is the focus of this study. Within the academic and logical-reflective scientific approach, this study wants to dialogue critically about the relationship between the pesantren's historical vision and the development of pesantren in a global context. The main data source in this study is the Virtual Pesantren. The object of his research is more directed at the study of substance and management of the virtual pesantren in building the strength of religious information providers that continue to attract users. The analysis of this study is descriptive qualitative. This research will discuss the learning management of virtual pesantren website content with content analysis method. Practically this method can be used for various purposes, such as; bridging the contents of international communication, comparing media or 'levels' in communication, detecting propaganda, explaining trends in communication content, etc (Weber, 1990: 9). The report is presented in the form of a comprehensive and objective narrative based on data that has been classified and verified 
beforehand. Presentation of educational programs in virtual pesantren, located in the domain and hosting https: //www. pesantrenvirtual. com/.

\section{Finding and Discussion}

The first time the virtual pesantren media was initiated through a mailing list with 41 members at the time. When its members reached 332 people, only the Virtual pesantren had its website which opened on September 27, 1999. The virtual pesantren was online at the address http://pesantren.hypermart.net/. In less than a year at the same domain (hypermart. Net) the virtual pesantren website has been visited nearly 40 thousand times, thus encouraging it to develop its domain. Since April 2000 the virtual pesantren has its domain, www.pesantrenvirtual.com (Rifai, 2009: 41). From the start of the declaration of Virtual Pesantren on the internet until now it has the following vision, mission, and goals:

1. The Vision of the Virtual Pesantren is a forum for developing, developing and utilizing an Islamic education media with a global perspective.

2. The mission of the Virtual Islamic Boarding School to develop media, facilities, and infrastructure to support the implementation of distance Islamic education, especially through the internet, and other media by using sophisticated and integrated communication technology.

3. The purpose of the Virtual Islamic Boarding School is to help Muslims who have difficulty attending and obtaining formal Islamic education and facilitate it with a variety of activities that are easily accessible, fast and more personal and are equipped with centralized and complete Islamic data and literature.

Until now, there are not many virtual pesantren. An example is a virtual of Islamic boarding school founded by Niam, a resident of Pati, Central Java, his web address is www.pesantrenvirtual.com, a virtual boarding school in Arabic Al Madinah founded by Abdul Rohman Siddiq, a resident of Semarang at the addresshttps://pesantrenalmadinah.com,http://islamlib.com/topik/pesantrenvirtual/https://p esantrenvirtualshahih.blogspot.com/.

The virtual Islamic boarding schools are managed with modern management (maybe even very modern because everything is done virtually). Each management has its communication and workflow in a neat and recorded (also virtual) systematics. There are editorial staff, lecturers, editors, and web teams, as well as daily executors and administrators. All are carried out professionally (as well as against the background of their respective professions). The management system is done virtually by making contact with others, utilizing internet facilities (email) between one board and another. They are mostly in far-off places and are carrying out their respective educational completion tasks. Each board has a communication channel and its workflow with a neat and scheduled system. For example, the web technician's part, if there is a problem on the website then the responsible management is responsible for resolving it.

Based on the results of data analysis of video material on the website and grub account as well as the communication behavior of virtual students with clerics or clerics can be drawn findings, where virtual Islamic boarding schools: first, in the learning process uses and is highly dependent on technology and information both the website, WhatsApp, email, and telephone; second, between the kyai/Islamic teacher with the respective students not face to face or interact directly as the traditional pesantren learning process, where between the virtual student and the kyai/Islamic teacher virtual is not bound by time and place in the learning process, the 
third material presented in the form of lectures tarbawi interpretation studies/Islamic studies in the form of analysis of religious problems in the contemporary era, fourthly, the methods presented by kyai/ustady in delivering material to students in the form of video lectures on tarbawi interpretation studies and Islamic studies in the form of religious problems in the contemporary era, fifth, communication interactions between kyai/Islamic teachers virtual with virtual students using email, WhatsApp, telephone, facebook. That is, despite using modern learning media, but still reviewing the yellow books that have been translated into Indonesian and using language of instruction that is straightforward and popular, because it carries the mission of proselytizing in society and across classes and generations.

Based on the description of learning management in Virtual Pesantren mentioned above, there are at least two unique things that are not found in traditional pesantren, namely: 1) virtual pesantren management is entirely run virtually. Communication between administrators is done by e-mail. Even though there is a physical building (which is also not permanent), it is only a kind of bahtsul matsail (consultative) forum to decide and study various religious issues. 2) between students and caregivers have never met with direct caregivers. They are only bound by the same goals and good intentions, which have brought together and united in the virtual realm.

As an important note with the emergence of Virtual Islamic Boarding School phenomenon, as a plan for the future, Virtual Islamic Boarding School can become an embryo of the emergence of educational institutions that can provide Islamic education, training, tarbiyah, and workshops by the demands of the times. Virtual boarding schools should meet a comprehensive boarding school directory, virtual libraries (and also conventional, of course) that provide contemporary Islamic discourses, as well as modern and systematic distance Islamic education systems (virtual lectures).

Some of the above descriptions confirm the conclusion that pesantren truly has important potential in developing modern education in the national and global contexts through their social roles. The intended social roles are as stated by Mastuhu (1994: 59). Islamic boarding schools have three main functions, namely: First, as an educational institution that organizes formal education (madrasas, public schools, and universities) and non-formal education that specifically teaches religion. Second, as an egalitarian, democratic and non-discriminatory social institution. The pesantren is also open for the wider community to consult with the Kiai about the problems of the Ummah. Third, as a religious broadcasting institution that reaches all groups and even remote areas.

Therefore, if individuals, groups or religious organizations want to develop pesantren, then they should re-read the values and traditions, and social roles of pesantren, so that more creative and transformative meanings do not reduce the original character of pesantren. For example the issue of independence, equality, justice, social solidarity, sincerity and simplicity (rubul ma had), how it should be developed in a virtual pesantren. Because these values if not innovative can be released will be able to release people from the negative effects of globalization. The principle of independence that has existed in pesantren, for example, is an educational pattern that continues to be developed in shaping the personality of an independent national generation. Santri (students) in Islamic boarding schools have been trained to be independent by regulating and taking responsibility for their needs (Kholil, 2011: 18). Such a principle is certainly a distinct advantage that should not be ignored in the development of pesantren model education.

The problem then is how to develop these values in the daily lives of students, and to reformulate traditional values in the context of Virtual pesantren. Because of the values of the pesantren 
tradition without any revitalization efforts through direct interaction between Kiai and Santri as in conventional pesantren, these values will become formalistic symbols of knowledge in cyberspace, and it will be difficult to become a source of reference in life attitudes. So, it is very possible that users are easily trapped in a crisis of spirituality. For this reason, the basic values (tasamuh, tawassuth, and tawazun) that have been referred to as pesantren need to be contextualized with the current conditions in the Virtual Pesantren. At this point, a dialogue between tradition (locality) and modernity needs to be carried out for the compatibility of civil society in the Indonesian context (nationality), for this reason, the historical value of the pesantren tradition needs to be translated into more universal concepts in accordance with the needs of the global community. This contextualization demand is to fight the formalism of some pesantren that carry the ideology of puritanism in the Middle East.

The demands of the pesantren's cultural and historical existence and global developments above require that pesantren must be able to wisely knit a triangular relationship between dimensions of locality, nationality, and globality. In the perspective of ukhuwah, the three are forms of linkage between ukhuwah Islamiyah (Islamic), ukhuwah wataniyyah (nationality), and ukhuwah basyariyah (humanity) (Triyanto, Anitah, and Suryani, 2013: 401). In considering the term Nurcholis Madjid, the three are forms between the dimensions of Islam (Islamicity), Indonesians (locality), and modernity (modernity)/science (Yasmadi 2002: 131). According to Waryani, locality can be interpreted in parallel with tradition, while the term modernity is parallel with global issues.

While Amin Abdullah uses the terms tradition and modernity. According to Amin Abdullah (2000) give the room of the religious teachings and traditions in their contextual form in the dynamics of social change is a necessity that must be addressed by creating a new face of religious teachings through the use of dialectical-hermeneutic-critical methods by elements of inherent historicity, both in religious tradition and modernity.

The meaning of Islam in this context, that pesantren, whatever the model, both salaf and khalaf, including virtual pesantren, must be able to raise the factors that cause Islamic education to be marginalized in building the education system. The emergence of the virtual pesantren actually, also dismissed the notion that Islam is a barrier to progress. Islam is claimed to be a value order that cannot coexist with modern science (Mukhibat, 2016: 264). This assumption is clear because it does not understand the universalism of Islamic teachings that have been practiced in pesantren. Islam in pesantren clearly shows that there is an organic relationship between science and faith. This organic relationship has been proven in classical Islamic history when Muslims had a truly cosmopolitan spirit long before the advent of pesantren in Indonesia.

The horizon of the meaning of cosmopolitanism and Islamic universalism reinforces the thesis of the necessity to give new meaning to the teachings of Islam that were developed through pesantren including virtual pesantren and other Islamic education. Pesantren must be able to give meaning to Islam dynamically, with broader dimensions such as liberation, domination, and injustice. The expression of the language of action of Muslims will disappear when the teachings of religious practice are only understood as a form of ritual, without reflection of feelings and mental experiences of actual phenomena. If this happens then the insight of universal grace from the presence of Islam has been reduced and exploited. The meaning of Islam like this, which should be understood by all the pesantren exponents in Indonesia, is the concept of a universal Islamic al-Islam which underlies a religion with a very strong impulse of universalism and breeds a culture with a cosmopolitan character (Madjid, 1988: 445). 


\section{Mukhibat}

The universal meaning of Islam in the global context as above means that it will deny the strict labelling of Islam as in the science of Islam, then what should be developed by pesantren is to make Islam rahmatan lil alamin, not just rahmatan lilmuslimin. Why should it be, this is caused by three things. First, the importance of awareness of the problem of universal humanity in the global era (humanity), the fact that people now inevitably are citizens of the world. Second, the problem of understanding nationality and Indonesian-ness in the country (nationality), even though Indonesia is a population of the earth, inevitably they are domiciled in one particular country. Third, the fact that every human being has spiritual elements, will always be restless and uneasy if without being based on the guidance of understanding comprehension and practice of Islam that is comprehensive, contemporary in responding to both Islamic and humanitarian problems.

Making the virtual pesantren a model of Indonesian education capable of overcoming the national identity crisis is a challenge in itself. This is due, virtual pesantren will be difficult to play as traditional pesantren as Indonesia's cultural heritage, although some virtual pesantren also holds the wealth potential of classical Islamic treasures which lies in the tradition of learning the yellow book which has been translated into Indonesian. The approach in virtual pesantren combines modern systems using information technology, and also uses traditional methods, like the sorogan and wetonan that exist in traditional pesantren. Also, the learning process emphasizes interactive dialogue with students.

To attract students, in studying the religious problems in the virtual pesantren using the "atta'shil walmuqaranab" approach (returning the proposition and comparison). The comparative discourse or muqarnas is still rarely implemented by existing pesantren institutions. In examining the problems of the virtual pesantren, it will explain the problems of various opinions by completing the argument and submitting it to the santri to choose which opinion is suitable for him.

The principle of pesantren education, whatever it's model, must always reflect the culture of the Indonesian nation. Creative and genuine interpretation of pesantren values of a must. Because of the ability of pesantren to do this will deliver boarding schools to a significant role in offering an education that can carry out community empowerment. When this can be well transformed by the pesantren, it is not impossible going forward, the pesantren has been able to knit the values of locality in a national and global context. On this basis, it also includes efforts that need to be made to make boarding schools as the center of Muslim civilization in Indonesia is to make the principles of education and culture in Islamic boarding schools as principles that also apply in other educational institutions. That is, the principles and culture of pesantren education need to be used as an alternative that can be adopted by the school education system or other formal education institutions. This is the reason why Indonesia must have a great opportunity to become the center of an excellent study of Islamic education in the world.

Thus, if the presence of a Virtual Islamic Boarding School is an answer to the need for the development of a message system in the digital era and the current global information, the Virtual Boarding School remains with the color and mission that does not change from conventional boarding schools. Virtual Pesantren management system must be managed with words that are straightforward, not frightening with verdicts 'stiff' and soothing, as in conventional pesantren, where there is a closeness in studying Islam together "learning Islam together

Thus it can be concluded that the virtual pesantren is a new model Islamic boarding school that does not have a real form and place but has the same function as other "conventional" boarding schools, namely as a tafaqqubfiddin institution that provides religious guidance. However, 
the predicate of pesantren as a "subculture" and the elements inherent in pesantren are difficult to fulfill by a virtual pesantren, the more appropriate name is the virtual/online study.

\section{Conclusion}

The existence of the Virtual Pesantren as one of the educational and propaganda strategies in the contemporary era is very effective, it cannot be denied, where the behavior of many millennial generations utilizes technology and information in each of their activities. Such conditions pesantren seem pesantren are facing a problematic situation between the fulfillment of global needs that are increasingly growing but on the other hand a commitment to maintaining the basic character of pesantren. The development of pesantren must continue to be built based on Islamic values which are tasamuh, tawassuth, and tawazun. The ability of pesantren to carry out continuity and change in bonding between the values of locality, nationality, and globality must be the basis of pesantren development. Why should it be, this is caused by three things. First, the importance of awareness of the problem of universal humanity in the global era (humanity). Second, the problem of understanding nationality and Indonesian-ness in the country (nationality). Third, the fact that every human being has spiritual elements, will always be restless and uneasy if without being based on the guidance of understanding comprehension and practice of Islam that is comprehensive.

\section{BIBLIOGRAPHY}

Abdullah, M. Amin. (2000). Dinamika Islam Kultural: Pemetaan Atas Wacana Keislaman Kontemporer. Yogyakarta: Mizan.

Adib, Muhammad. (2013) Ketika Pesantren Berjumpa Dengan Internet: Sebuah Refleksi Dalam Perspektif Cultural Lag, Jurnal Pusaka, 1(1).

Ali, Anwar, (2010), Pembaharuan Pendidikan Di Pesantren Lirboyo Kediri. Yogyakarta: Pustaka Pelajar. Aziz, Helmi and Nadri Taja. (2016). Kepemimpinan Kyai Dalam Menjaga Tradisi Pesantren (Studi Deskriptif di Pondok Pesantren Khalafi Al-Mu'awanah Kabupaten Bandung Barat). Ta'dib: Jurnal Pendidikan Islam, 5(1), 2016

Bhagaskoro, P., Pasopati, R. U., Syarifuddin, S. (2019). Pancasila Dalam Interaksi Kearifan Lokal

Dan Ideologi Transnasional, Jurnal Inovasi Sosial Politik, 1(2), (Oktober), 2019.

Damanhuri, A., Mujahidin, E., and Hafidhuddin, D. (2013). Inovasi Pengelolaan Pesantren Dalam Menghadapi Persaingan di Era Globalisasi. Ta'dibuna: Jurnal Pendidikan Islam, 2(1), 2013.

Djasadi, Djasadi. (2014). Kontribusi Pesantren Dalam Perkembembangan Studi Islam. Jurnal Intelegensia, 3(1).

Ghofar, Muhammad. (2017). Pesantren of Learning Organization: Analisis Transformasi Pengembangan Pondok Pesantren di Indonesia. In Proceedings ANCOMS 2017. Surabaya.

Ilyasin, Mukhamad. (2020). Transformation of Learning Management: Integrative Study of Islamic Boarding School Curriculum, Dinamika Ilmu, 20(1), 2020

Kholil, Muhamad. (2011). Menggagas Pesantren Sebagai Pusat Peradaban Muslim di Indonesia. Media Akademika, 26(3).

Madjid, Nurcholis. (1997). Bilik-Bilik Pesantren Sebuab: Potret Perjalanan. Jakarta: Paramadina. Madjid, Nurcholish. (1988). Islam Doktrin Dan Peradaban: Sebuab Telaab Kritis Tentang Masalah Keimanan, Kemanusiaan Dan Kemoderenan. Yayasan Wakaf Paramadina. 
Mastuhu. (1994). Dinamika Sistem Pendidikan Pesantren: Suatu Kajian Tentang Unsur Dan Nilai Sistem Pendidikan Pesantren. Jakarta: INIS.

Muhakamurrohman, Ahmad. (2014). Pesantren: Santri, Kiai, Dan Tradisi. IBD A: Jurnal Kajian Islam Dan Budaya, 12(2), 2014.

Mukhibat, M. (2016). Affirming the Historical Vision of Madrasah in the Global Context: Religious, Popular, Centers of Excellence, Core of Learning Society, and Diversity. TAW ARIKH, 7(2).

Mukhibat, M. and Ghafar, M. (2019), Virtual Pesantren: New Trend of Islamic Education Model in Indonesia, International Journal of Innovation, Creativity and Change (IJICC), 5(2), 2019

Mukhibat, M. (2014). Deradikalisasi dan Integrasi Nilainilai Pluralitas dalam Kurikulum Pesantren Salafi Haraki di Indonesia. Al Tahrir: Jurnal Pemikiran Islam, 14(1), (Mei), 2014

Mukti, Abdul Hady. (2002). Pengembangan Metodologi Pembelajaran Di Salafiyah. Jakarta: Departemen Agama RI.

Saputra, R., Nazim, A.M., and Islamiyah, U. H. (2017). Dakwah Strategy Persaudaraan Professional Muslim (PPM) Aswaja" through the Internet. International Journal of Academic Research in Business and Social Sciences, 7(6), 2017.

Supratman, Lucy Pujasari. (2018). Penggunaan Media Sosial oleh Digital Native, Jurnal Ilmu Komunikasi, 15(1), (Juni), 2018

Tafsir, Ahmad. (2008). Ilmu Pendidikan Menurut Perspektif Islam. Bandung: Remaja Rosda Karya.

Triyanto, E., Anitah, S., and Suryani, N. (2013). Peran Kepemimpinan Kepala Sekolah Dalam Pemanfaatan Media Pembelajaran Sebagai Upaya Peningkatan Kualitas Proses Pembelajaran. Teknologi Pendidikan, 1(2).

Weber, Robert Philip. (1990). Basic Content Analysis: (Quantitative Applications in the Social Sciences), Sage Publication,

Wahid, Abdurrahman. (2001). Menggerakkan Tradisi: Esai-Esai Pesantren. Yogyakarta: LKiS.

Wiesenfeld, Batia M., Sumita Raghuram, and Raghu Garud, (1999), Communication Patterns as Determinants of Organizational Identification in a Virtual Organization. Organization Science, 10(6)

Yasmadi, Y. (2002). Modernisasi Pesantren: Kritikan Nurchlish Madjid Terhadap Pendidikan. Jakarta: Ciputat Press.

Yunus, Mahmud. (1990). Sejarah Pendidikan Islam di Indonesia. Jakarta: Hidayakarya. 